Available online at GSC Online Press Directory

GSC Biological and Pharmaceutical Sciences

e-ISSN: 2581-3250, CODEN (USA): GBPSC2

Journal homepage: https://www.gsconlinepress.com/journals/gscbps

(RESEARCH ARTICLE)

\title{
Performance, carcasses, cholesterol and beta-carotene of rabbit meat fed with concentrate and carrot (Daucus carota) leaves
}

\author{
Puspani E, Candrawati DPMA and Bidura IGNG* \\ Faculty of Animal Science, Udayana University, Jl. PB Soedirman, Denpasar, Bali, Indonesia.
}

Publication history: Received on 28 June 2020; revised on 04 July 2020; accepted on 06 July 2020

Article DOI: https://doi.org/10.30574/gscbps.2020.12.1.0207

\begin{abstract}
This study aims to observe the effect of concentrated levels in carrot leaf based feeds to improve performance, carcass and $\beta$-carotene content in local rabbit meat at 8 weeks. This study used a feed experiment using 120 local 8 -week-old male rabbits divided four group treatments and 6 replications. The four group treatments were rabbits fed on carrot leaf based rations with supplementation: $0 \%$ concentrate as a control (A), $10 \%$ (B); $20 \%$ (C); and 30\% (D), respectively. Each treatment consisted of six replication cages with five rabbits per cage. The results showed that feed consumption, final body weight, weight gain, carcass weight, and percentage of carcasses in Groups B, C and D, were significantly $(\mathrm{P}<0.05)$ higher than Group A. The lowest cholesterol content was found in rabbits group A $(\mathrm{P}<0.05)$. In contrast, the highest beta-carotene levels of meat $(\mathrm{P}<0.05)$ were found in group A. It was concluded that supplementation of $10-20 \%$ concentrate in carrot leaf based rations could increase live weight gains, carcass weight, carcass percentage, and feed efficiency in local rabbits up to 8 weeks old. The highest content of $\beta$-carotene in rabbit meat was found in feeding $100 \%$ of carrot leaves.
\end{abstract}

Keywords: Daucus carota; Cholesterol; $\beta$-carotene; Rabbit

\section{Introduction}

Improving the performance of rabbits is an alternative that can be used as a source of high-quality animal protein, and diversification of animal protein sources, but white rabbit meat, less favored by consumers. The advantage of rabbits as a producer of meat, namely the quality of meat, where high protein content with low fat content, and better than other livestock meat, such as beef and pork. The protein content of rabbit meat is $20.10 \%$, while cattle and pigs are: $16.3 \%$ and $11.9 \%$. The fat content of rabbit meat is $10.2 \%$, while cattle and pigs are: $28 \%$ and $45 \%$ [1]. Rabbits are one of the alternative livestock that have great potential to be breeded to meet the needs of animal protein in the Indonesian people as well as toincrease the welfare of farmers.

In intensive rabbit breeding patterns, the largest production cost comes from feed, which is around 60-70\%. Therefore, the breeder must do it with efforts to increase feed efficiency. Rabbit livestock business is the choice to be cultivated, because the feed does not compete with human needs. Giving high forage to rabbits can improve feed efficiency. Rabbits can be raised by providing forage food combined with agricultural waste [2]. One of agricultural waste that can be utilized is carrot leaf (Daucus carota). Carrot leaves contain crude protein 18.71\%; crude fiber 15.69\%; crude fat 3.19\%; and ash $33.58 \%$ [3]. The data shows that carrot leaves have higher protein content and low crude fiber, so that carrot leaves can be a good alternative feed as rabbit feed. However, the metabolic energy content is low and has not been able to meet the needs of rabbits for the production process [4]. Therefore, it needs to be supplemented with concentrate feed so that rabbit productivity can be optimal.

${ }^{*}$ Corresponding author: Bidura IGNG

Copyright (C) 2020 Author(s) retain the copyright of this article. This article is published under the terms of the Creative Commons Attribution Liscense 4.0. 
Bioconversion of $\beta$-carotene by its cleavage enzyme has been widely studied. An interesting recent study has shown that the expression and activity of major cleavage enzymes in the intestine are regulated by the feed consumed and genetics [5].

The higher the level of concentrate in grass-based rations, causing an increase in digestible energy, metabolic energy, and energy that is retained in the body of rabbits [6]. Likewise, the protein that is retained in the body of the rabbit is increasing. The local rabbit fed basal native grasses with supplementation of concentrate produce carcass weight and retention of energy and protein in the body was rather than unsupplemented [1]. The nutritional needs of local rabbits in the tropics are: $16 \%$ protein with $2600 \mathrm{kcal} / \mathrm{kg}$ of metabolic energy [7]. To get optimal rabbit growth, it is necessary to supplement with concentrate [6].

Carrots (Daucus carota L.) is a type of vegetable that is well known as a source of provitamin-A (carotenoids). The carotenoid content is very high and much higher than tomatoes. In addition to the high carotenoid content, carrot production in Indonesia is quite abundant. Carrot production in Indonesia reached 350,170 tons and leaf waste produced very much as a competitive alternative animal feed. The $\beta$-carotene compound as an active carcass color agent, so it is very important for its role in increasing the color of white rabbit carcass to red which is very preferred by consumers [8]. Carrot leaves contain high phytochemical compounds, such as flavonoids, phenolics, terpenoids, steroids, tannins, carotenoids and high beta carotene [9].

It is interesting to study its usefulness as a natural feed supplement is carrot leaf because it is a waste of carrot harvesting. Based on this, researchers are interested in examining the effect of concentrate levels in carrot leaf-based rations to improve performance, carcass, and $\beta$-carotene content in rabbit meat.

\section{Material andmethods}

\subsection{Animals and experimental design}

This study used 120 healthy male local rabbits aged 56 days with homogeneous body weight $(651.82 \pm 11.06 \mathrm{~g})$. This study used a Carrot leaf based rations with supplementation: $0 \%$ concentrate as a control (A), $10 \%$ (B); $20 \%$ (C); and $30 \%$ (D), respectively. Each group treatments in six replication with five rabbits per cages. The size of each cages was: $100 \times 50 \times 40 \mathrm{~cm}^{3}$ (length $\mathrm{x}$ width $\mathrm{x}$ height). Concentrated feed was pellet form and rabbits had free access to feed and drinking water during the experiment period. Body weight and feed intake are registered every days. The observed variables were: feed consumption, weight gain, feed efficiency, carcass, carcass percentage, protein content and $\beta$ carotene content in rabbit meat.

\subsection{Live performance.}

Body weight, live weight gains (LWGs), feed intake and feed conversion ratio for rabbits were recorded separately every days. Feed consumption (grams per rabbit) was recorded every days on each replication. Total feed intake for each test was measured during the trial period. Feed Conversion Ratio (FCR) was calculated as grams of feed consumed per gram of body weight obtained. FCR is an indicator to measure feed efficiency. The lower the FCR value, the higher the feed efficiency. The ingredients of the experimental diet and chemical composition are shown in Table 1.

\subsection{Slaughter procedures}

At the end of the study, all rabbits were slaughtered to obtain carcass weight and carcass percentage. Carcass weight was obtained by slaughtered rabbits by cutting the jugularis vein in the neck to remove blood from the rabbit's body [10]. The percentage of carcasses was calculated as the weight of fresh carcass divided by body weight of the rabbit before being slaughtered, multiplied by 100\% [11]. Slaughtered rabbits were then skinned, then the internal organs and digestive tract are removed. Head weight, thymus, trachea, esophagus, heart, lungs, liver and kidneys were removed from the weight of slaughtering, to obtain carcass weight. The percentage of carcasses was the ratio between carcass weight and rabbit weight before slaughter. 
Puspani et al. / GSC Biological and Pharmaceutical Sciences, 2020, 12(01), 041-047

Table 1 Ingredients and nutrient composition content of the feed of growing rabbits aged 8-16 weeks

\begin{tabular}{llllllll}
\hline Ingredients & $\begin{array}{l}\text { Compo- } \\
\text { sition (\%) }\end{array}$ & $\begin{array}{l}\text { ME } \\
\text { (Kcal/kg) }\end{array}$ & $\begin{array}{l}\text { Crude } \\
\text { Protein } \\
\text { (\%) }\end{array}$ & $\begin{array}{l}\text { Ether } \\
\text { Extract (\%) }\end{array}$ & $\begin{array}{l}\text { Crude } \\
\text { Fibre (\%) }\end{array}$ & $\begin{array}{l}\text { Ca } \\
\text { (\%) }\end{array}$ & P (\%) \\
\hline Fish meal & 2.0 & 59.4 & 0.8 & 0.18 & 0.02 & 0.154 & 0.078 \\
Pollard & 35.10 & 456.3 & 5.27 & 1.40 & 3.51 & 0.05 & 0.116 \\
Yellow corn & 49.0 & 1651.3 & 7.35 & 1.91 & 0.98 & 0.01 & 0.049 \\
Coconut meal & 7.0 & 107.8 & 1.47 & 0.13 & 1.05 & 0.01 & 0.014 \\
Pignox & 6.4 & 125.4 & 0.19 & 0.01 & 0 & 0.06 & 0.001 \\
NaCl & 0.3 & - & - & - & - & - & - \\
\hline Total & 100 & 2400.24 & 15.08 & 3.63 & 5.56 & 0.28 & 0.26 \\
\hline
\end{tabular}

*) The composition "Pignox" in every gram contains: 40 mg Olaquindox; 800 IU Vitamn D3; 5000 IU of vitamin A; 2 mg of vitamin E; $0.4 \mathrm{mg}$ of vitamin B1; $0.8 \mathrm{mg}$ of vitamin K3; $0.4 \mathrm{mg}$ of vitamin B6; $0.8 \mathrm{mg}$ of vitamin B2; 8 ug of vitamin B12; $8 \mathrm{mg}$ of nicotinic acid; 6 mg Ca-D-pantothenate; $200 \mathrm{mg}$ of cholin chloride; $40 \mathrm{mg}$ of methionin; $8 \mathrm{mg} \mathrm{Mn} ; 0.4 \mathrm{mg} \mathrm{I} ; 16 \mathrm{mg} \mathrm{Fe} ; 0.2 \mathrm{mg} \mathrm{Co} ; 20 \mathrm{mg} \mathrm{Cu}$; and $20 \mathrm{mg}$ Zn (Medion, Bandung-Indonesia; Kementan RI No.D 06121109FTS.2); **)according to [12].

\subsection{Measurement of cholesterol levels in meat}

Observation of meat cholesterol levels was done once, namely in the last week of the study using carcass meat taken in each unit of the experiment. Cholesterol analysis using the Lieberman-Burchad method from [13]. The sterol solution in chloroform was witnessed with acetic acid anhydrous concentrated sulfuric acid. In later tests the color was from bluish green to green, depending on the cholesterol level of the sample. The resulting solution was listed on the spectrophotometer to obtain optical density (DO). The results were then compared with DO from standard solutions, so that the amount of cholesterol in the sample can be calculated.

\subsection{Statistical analysis}

All of data were analyzed with one-way variance and if there was a significantly difference $(\mathrm{P}<0.05)$ between treatments, it was followed by Duncan's multiple range test.

\section{Results}

Table 2 showed that administration of concentrate at the level of 10-30\% in carrot leaf based ration, statistically showed a significantly difference $(\mathrm{P}<0.05)$ in final body weight, live weight gains, feed consumption, feed conversion ratio (FCR), slaughtered weight, carcass weight, carcass percentage, and beta-carotene content in rabbit meat. Cholesterol content in rabbit meat was significantly difference $(\mathrm{P}<0.05)$ between treatments. More details are presented in Table 2.

\subsection{Growth Performance and Carcasses}

The final body weight of rabbits fed with carrot leaves without supplementation concentrate (A) was $1560.05 \mathrm{~g} / \mathrm{head}$ (Table 2). The final average body weight of rabbits showed a significant increase $(\mathrm{P}<0.05)$ with the supplementation of $10 \%$ concentrate (B), 20\% concentrate (C), and 30\% concentrate (D), which was: $8.31 \% ; 12.55 \%$; and $15.11 \%$ higher than controls. Likewise, the weight gain of rabbits treated $\mathrm{B}, \mathrm{C}$, and D experienced a significant increase $(\mathrm{P}<0.05)$, namely: 14.31\%; 21.02\%; and 25.67\% higher than the control (A). Supplementation of concentrates in Carrot leaf based ration significantly $(\mathrm{P}<0.05)$ increased feed consumption (carrot leaves and concentrates). Feed intake in rabbits Group $\mathrm{B}, \mathrm{C}$ and $\mathrm{D}$, were: $7.69 \% ; 13.09 \%$; and $12.69 \%$ were significantly $(\mathrm{P}<0.05)$ higher than controls, but between treatments $\mathrm{B}, \mathrm{C}$ and $\mathrm{D}$ did not show any significant difference $(\mathrm{P}>0.05)$. More details are presented in Table 2.

Feed Conversion Ratio (FCR) is a comparison between feed consumption and live weight gains in the same time unit. The average FCR in control rabbits was: 3.95/head (Table 2). Concentrated supplementation in Group B, C, and D of rabbits significantly different $(\mathrm{P}<0.05)$ can improve feed efficiency: 5.82\%; 6.58\%; and 10.38\% higher than controls. 
Table 2 Carcass and performance of rabbits (8-16 weeks old) fed concentrate on carrot (Daucus carota) leaf-based ration.

\begin{tabular}{|c|c|c|c|c|c|}
\hline \multirow[t]{2}{*}{ Variabel } & \multicolumn{4}{|c|}{ Treatment Group ${ }^{1)}$} & \multirow[t]{2}{*}{ SEM $^{2)}$} \\
\hline & $\mathrm{A}$ & $\mathrm{B}$ & $\mathrm{C}$ & $\mathrm{D}$ & \\
\hline Initial body weight (g/head) & $650.37 a$ & $649.83 a$ & $654.91 \mathrm{a}$ & $652.57 a$ & 10.681 \\
\hline Final body weigt (g/head) & $1560.05 b$ & $1689.73 a$ & $1755.82 \mathrm{a}$ & $1795.81 \mathrm{a}$ & 38.186 \\
\hline Body weight gains (g/head/56 days) & $909.68 b^{3)}$ & 1039.90a & $1100.91 \mathrm{a}$ & $1143.24 a$ & 40.062 \\
\hline Live weight gains (g/head/days) & $16.24 \mathrm{~b}$ & $18.57 a$ & $19.66 \mathrm{a}$ & $20.42 a$ & 0.629 \\
\hline Feed consumption (g/head/days) & $64.15 b$ & $69.08 \mathrm{a}$ & $72.55 a$ & $72.29 \mathrm{a}$ & 2.307 \\
\hline FCR (feed consumption:LWGs) & $3.95 b$ & $3.72 \mathrm{a}$ & $3.69 \mathrm{a}$ & $3.54 \mathrm{a}$ & 0.069 \\
\hline Slaughtered weight (g/head) & $1548.59 b$ & $1686.62 \mathrm{a}$ & $1750.35 a$ & $1790.06 a$ & 41.704 \\
\hline Carcass weight (g/head) & $728.30 \mathrm{~b}$ & $838.92 \mathrm{a}$ & $876.58 \mathrm{a}$ & $902.37 \mathrm{a}$ & 30.513 \\
\hline Carcass percentage (\%) & $47.03 \mathrm{~b}$ & $49.74 \mathrm{a}$ & $50.08 \mathrm{a}$ & $50.41 \mathrm{a}$ & 0.618 \\
\hline Meat cholesterol (mg/100g) & $158.52 b$ & $161.06 \mathrm{~b}$ & $168.73 a$ & $170.39 a$ & 1.815 \\
\hline Beta-carotene in meat $(\mu / g)$ & $62.94 \mathrm{a}$ & $60.72 \mathrm{a}$ & $49.27 \mathrm{~b}$ & $44.51 \mathrm{~b}$ & 2.394 \\
\hline
\end{tabular}

Note: Level of concentrate in carrot leaf based rations, is: 0\% (A); 10\% (B); 20\% (C); and 30\% (D), repectively.SEM: standard error of treatment means. Means with different superscripts within raw values are significantly different $(\mathrm{P}<0.05)$.

Supplementation of concentrates in carrot leaf based ration significantly $(\mathrm{P}<0.05)$ increased slaughtered weight $($ Table 2). The average slaughtered weight in rabbits group B, C, and D, were: $78.91 \% ; 13.03 \% ; 15.59 \%$ was significantly $(\mathrm{P}<0.05)$ higher than the control, but between treatments $\mathrm{B}, \mathrm{C}$ and $\mathrm{D}$ did not show any significant difference $(\mathrm{P}>0.05)$. Carcass weight and percentage of carcasses of rabbits which were given carrot leaves without concentrate supplementation as a control, were: $728.30 \mathrm{~g} / \mathrm{head}$ and $47.03 \%$ (Table 2). Average carcass weight in rabbits group B, C, and $D$, were: $15.19 \% ; 20.36 \%$; and $23.90 \%$ significantly $(\mathrm{P}<0.05)$ higher than controls. Likewise, the average percentage of carcasses in rabbits treated B, C, and D, were: 5.76\%; 6.49\%; and 7.19\% were significantly $(\mathrm{P}<0.05)$ higher than controls.

\subsection{Cholesterol and $\beta$-carotene}

The lowest cholesterol level in rabbit meat was found in the administration of 90-100\% Carrot leaves (groups C0 and $\mathrm{C} 1)$, and showed significant differences $(\mathrm{P}<0.05)$ compared to the treatment groups $\mathrm{C} 2$ and $\mathrm{C} 3$. Cholesterol levels in rabbit meat in groups C2 and C3 were: $21.72 \%$ and $29.28 \%$ significant $(\mathrm{P}<0.05)$ higher than group C0. More details are presented in Table 2 . The beta-carotene content in rabbit meat decreased significantly $(\mathrm{P}<0.05)$ with the addition of concentrate in the ration (Table 2). The $\beta$-carotene content in rabbit meat in treatment B was 3.53\% lower (P>0.05) rather than treatment A. Supplementation of $20 \%$ concentrate (treatment C) and 30\% concentrate (treatment D) significantly $(\mathrm{P}<0.05)$, reduced $\beta$-carotene content in rabbit meat, namely: $21.72 \%$ and $29.28 \%$ lower compared to controls.

\section{Discussion}

\subsection{Growth Performance and Carcasses}

Supplementation of concentrates in carrot leaf based rations significantly improved the growth performance of rabbits. Concentrate is a mixture of several types of quality feed, so that the high protein content is above $21 \%$ and crude fiber is lower than $18 \%$, and the dry matter digestibility is above $75 \%$. To improve the performance of rabbits, feeding must be regulated, so that the balance between forage and concentrate can meet the nutrient requirements for rabbit production [14]. Concentrated supplementation combined with carrot leaf herbs will improve morphology of the small intestine by different mechanisms [15]. Carrot leaves contain phytochemical compounds, such as flavonoids and beta carotene which are quite high [9]. Flavonoids and beta carotene can in inhibite of pathogenic microbes and endotoxins in the gastro intenstinal tract and increased activity of the pancreas in broiler [16,17]. Some studies have found that foraging as much as $60-80 \%$, while concentrates as much as $20-40 \%$ of the total amount of feed given, can give the best results. The highest performance of rabbits was in giving rations with $16 \%$ protein and $2800 \mathrm{kcal} / \mathrm{kg}$ metabolizable 
energy compared to $2200 \mathrm{kcal} / \mathrm{kg} ; 2500 \mathrm{kcal} / \mathrm{kg}$ and $3100 \mathrm{kcal} / \mathrm{kg}$ metabolizable energy [9]. Thet rabbits fed with higher protein diets produced higher performance compared to low protein diets [9]. Protein, carbohydrates, fats, minerals, vitamins, and water are nutrients that are needed by rabbits [18, 2].

Feed conversion ratio (FCR) value is the ratio between feed consumption and live weight gains in the same time unit. Is an indicator to assess the level of feed efficiency. The lower FCR value means higher feed efficiency. The level factor of carrot leaf forage with concentrate affects feed consumption, growth and feed efficiency. Contrary to the results of research, that the forage-concentrate balance in the ration, and the ration giving factor, apparently had no effect on rabbit weight gain [19]. The content of crude fiber in feed can also affect feed efficiency. The use of high-fiber food in rabbit ration in general, is not recommended because of the negative effects given to nutritional utilization and performance, such as decreased digestibility of feed and decreased weight gain as well as decreased feed efficiency [9]. Some types of crude fiber feed have the effect of increasing the activity of the gizzard function, resulting in increased reflux of the digestive tract and digestive enzymes in poultry [20].

The carcass weight and percentage of the carcass of the rabbit increases with a concentrate of $10-30 \%$ in its ration. This increase is due to the concentration of food with high protein and energy content, and has a high digestibility, so it can meet the needs for optimal rabbit growth [21]. The administration of concentrate in rabbits can stimulate the growth of rabbits with high carcass weight [4]. It was also reported that the weight and percentage of carcasses of rabbits were lowest when given grass or carrot leaves without supplementation of the concentrate.

\subsection{Cholesterol and $\beta$-carotene}

The higher the supplementation of the concentrate, causing decreased consumption of carrot leaves. This happens because the concentrate is given first, followed by then carrot leaves. Rabbits will stop consuming rations when their energy needs are fulfilled. Carrot leaves contain phytochemical compounds, such as flavonoids, saponins, and tannins. Flavonoids, similar to estrogen which can reduce yolk cholesterol, and increase high density lipoprotein levels in meat of broiler [22, 23]. Phytochemical compounds from herbal leaves (Curcuma longa) in diets can reduce the cholesterol content of rabbit meat [24]. Xanthophil compounds, such as lutein, zeaxanthin, meso-zeaxanthin, astaxanthin, and canthaxanthin are carotene oxygen derivatives [25]. In addition, lower levels of meat cholesterol in treatments A and B can be caused by the high content of crude fiber in carrot leaves, which plays an important role in binding and eliminating cholesterol $[26,27,28]$. The increase levels of crude fiber in feed can reduce feed consumption, percentage of abdominal fat, and LDL-blood cholesterol, but do not affect final body weight [29].

Color is an important quality of food, because it influences perceptions of the quality and intensity of tastes and tastes of consumers, and purchasing decisions [30]. The color of rabbit meat is white, so it is less liked by consumers [17]. Color greatly affects the acceptability of consumers, because it is identical with quality. The color of meat is influenced by feed, stress, $\mathrm{pH}$, and oxygen [25]. The color of the meat measured consists of three parameters, namely: brightness, redness, and yellowish. Meat color is a combination of several factors and the intensity of each color has characteristics, namely the color pattern and color intensity. The color favored by consumers is the bright red flesh color. The appearance of a bright red color in meat is caused by the presence of oxygen bonds in the Fero ion $\left(\mathrm{Fe}^{2+}\right)$ in the molecular structure of myoglobin [31].

The color of rabbit meat seen from its beta-carotene content turns out to be redder with carrot leaves compared with the concentrate. This increase is due to the higher $\beta$-carotene content in carrot leaves than the concentrate. Increasing the amount of concentrate given to rabbits will automatically reduce consumption of carrot leaves, thereby affecting the $\beta$-carotene content in rabbit meat. The color of rabbit meat given carrot leaves (Group A) has a much higher yellow color than treatments $\mathrm{C}$ and $\mathrm{D}$. The increase in the beta-carotene content of meat is strongly related to the ingredients used in the ration. Carrot leaves contain high phytochemical compounds, such as flavonoids, phenolics, terpenoids, steroids, tannins, carotenoids and high beta carotene [4]. Specifically, lutein compounds are active yellow dyes. The increase supplementation of herbal leaves in the ration resulted in a linear increase in egg yolk color [32, 22]. The local rabbits fed supplemental herbal leaves could increase the intensity of the color of rabbit meat compared without the addition of herbal leaf flour [33]. Conflicting results, that an increase in the content of beta-carotene (flavonoids) in the diet apparently had no effect on increasing the color of the meat [34,35].

\section{Conclusion}

It was concluded that supplementation of 10-20\% concentrate in Carrot leaf based rations could increase weight gain, carcass weight, carcass percentage, and feed efficiency in local rabbits aged 8-16 weeks. Beta-carotene content in rabbit meat has increased with the addition of Carrot leaves, but decreased meat cholesterol content. 


\section{Compliance with ethical standards}

\section{Acknowledgments}

The author would like to thank the Rector and Dean of the Faculty of Animal Husbandry, Udayana University for the facilities and funds provided so that research can be completed.

\section{Disclosure of conflict of interest}

All authors have read and agreed to send this manuscript to GSC Biological and Pharmaceutical Sciences. The authors state that this research was carried out in the absence of commercial or financial relationships that could create a conflict of interest.

\section{Statement of ethical approval}

All procedures performed in experiments involving experimental animals were in accordance with the Use of Laboratory Animals at the Faculty of

\section{References}

[1] Nuriyasa IM. (2017). Pemeliharaan Kelinci Lokal di Daerah Dataran rendah Tropis. Percetakan Swasta Nulus, Jl. Tukad batanghari VI.B/9, Denpasar-Bali

[2] Nuriyasa IM, Yupardhi WS, Putri BRT and Warmadewi DA. (2017). Finacial trade analysis of local rabbit livestock business that use coffee skin waste product as animal feed. J. Biol. Chem. Research., 34, 454-459.

[3] Puspani E, IGNG Bidura, IK Sumadi, IM Nuriyasa and DPMA Candrawati. (2019). Growth performance, meat cholesterol and $\beta$-carotene content in rabbit fed with Carrot leaves, grass, and concentrates. International Journal of Multidisciplinary Approach and Studies, 06, 32-41.

[4] Shete V and L Quadro. (2013). Mammalian Metabolism of $\beta$-Carotene: Gaps in Knowledge. Nutrients, 5, 48494868.

[5] Nuriyasa I.M., I. G. N. G. Bidura, AW Puger and E Puspani. (2018). The Effect of Concentrate Supplementation in Diet Base Local Grasses on the Performance and Energy-Protein Retention of Local Rabbit. Eurasian Journal of Analytical Chemistry,13, 1-8.

[6] Nuriyasa IM, Mastika IM, Mahardika GD, Kaqsa IW and Aryani IGAG. (2014). Energy and protein retention of local rabbit housed in different cages. J Biol Chem Res, 31, 800-807.

[7] Ayssiwede SB, A Dieng, H Bello, CAA. Chrysostome, MB Hane, A Mankor, M Dahouda, MR Houinato, JL Hornick, and A Missohou. (2011). Effects of Moringa oleifera (Lam.) leaves meal incorporation in diets on growth performances, carcass characteristics and economics results of growing indigenous senegal chickens. Pakistan Journal of Nutrition, 10, 1132-1145.

[8] Nuriyasa IM, IM Mastika, AW Puger, E Puspani dan and IW Wirawan. (2013). Performans kelinci lokal (Lepus nigricollis) yang diberi ransum dengan kandungan energi berbeda. Majalah Ilmiah Peternakan, 16, 12-17.

[9] Alhaidary A, HE Mohamed and AC Beynen. (2010). Impact of Dietary Fat Type and Amount on Growth Performance and Serum Cholesterol in Rabbits. American Journal of Animal and Veterinary Sciences, 5, 60-64.

[10] Lukefahr SD, WD Hohenboken, PR Cheeke, NM Patton and WH Kennick. (1981). Carcass and Meat Characteristics of Plemish Giant and New Zealand White Purebreed and Terminal - Crossbred Rabbits. J. Of Appl, Res., 4, 66-72.

[11] Scott ML, MC Neisheim MC and RJ Young. (1982). Nutrition of The Chickens. 2nd Ed. Publishing by: M. L. Scott and Assoc. Ithaca, New York.

[12] Plummer DT. (1977). An Introduction to Practical Biochemestry. McGraw-Hill Book Co., Ltd. New Delhi.

[13] Scott ML, MC Neisheim and RJ Young. (1982). Nutrition of The Chickens. 2nd Ed. Publishing by: M. L. Scott and Assoc. Ithaca, New York.

[14] Karukarach T, C Rakangthong, C Bunchasak and T Poeikhampha. (2016). Comparative effects of blended herbal extracts and mixed prebiotics on growth performance, carcass yields and intestinal morphology of broiler chickens. International Journal of Poultry Science, 15, 264-270. 
Puspani et al. / GSC Biological and Pharmaceutical Sciences, 2020, 12(01), 041-047

[15] Kartadisastra HR. (1997). Penyediaan dan Pengelolaan Pakan Ternak Ruminansia. Penerbit Kanisius. Yogyakarta.

[16] Xiccato G, Bernardini M, Castellini C, Dalle Zotte A, Queaque PI and Trocino A. (1999). Effect of postweaning feeding on the performance and energy balance of female rabbits at different physiological states. Journal of animal science, 77, 416-426.

[17] Qisthon A. (2012). The effect of ration with certain ratio of forage-concentrate and the time of feeding on productivity of male local rabbits. Jurnal Penelitian Pertanian Terapan, 12, 69-74.

[18] Mateos GG, Jimenez-Moreno E, Serrano MP and Lazaro R. (2012). Poultry response to high levels of dietary fiber sources varying in physical and chemical characteristics. The Journal of Applied Poultry Research, 21, 156-174.

[19] Parigi Bini R, Xiccato G, de Blas C and Wiseman J. (1998). The nutrition of the rabbit. Ed. De Blas C., Wiseman J. CABI.

[20] Bidura, IGNG, IBG Partama, BRT Putri and L Watiniasih. (2017). The effect of water extract of two leaves (Allium sativum and Sauropus androgynus) on the egg production and yolk cholesterol level in layer hens. Pakistan Journal of Nutrition, 15, 23-31.

[21] Santoso U, Y Fenita Kususiyah and IGNG Bidura. (2015). Effect of Fermented Sauropus androgynus leaves on, meat composition, amino acid and fatty acid compositions in broiler chickens. Pakistan journal of nutrition, 14, 759-807.

[22] Cervantes-Valencia ME, Yazmin Alcala-Canto, Abdelfattah ZM Salem, Ahmed E Kholif, Adriana Margarita Ducoing-Watty, María Josefa Bernad-Bernad and Carlos Gutiérrez-Olvera. (2015). Influence of Curcumin (Curcuma longa) as a natural anticoccidial alternative in adult rabbits: First Results, Italian J. of Anim. Sci., 14, 3838.

[23] Von-Lintig J. (2013). Carotenoids. Arch. Biochem. Biophys., 539, 99-101.

[24] Ghasi S, Nwobodo E and Ofili JO. (2000). Hypo-cholesterolemic effects of crude extract of leaf of Moringa oleifera Lam in high-fat diet fed Wistar rats. J. Ethno. pharmacol, 69, 21-25.

[25] Oladunjoye IO, Ojebiyi O and Amao OA. (2010). Effect of feeding processed cassava (Manihot esculenta crantz) peel meal based diet on the performance characteristics, egg quality and blood profile of laying chicken. Agric. Trop. Subtrop, 43, 119-126.

[26] Olugbemi TS, Mutayoba SK and Lekule FP. (2010). Effect of Moringa (Moringa oleifera) inclusion in cassava based diets fed to broiler chickens. Int. J. Poult. Sci., 9, 363-367.

[27] Mandey JS, YHS Kowel, MN Regar and JR Leke. (2017). Effect of different level of energy and crude fiber from sawdust in diets on carcass quality of broiler. J. Indonesian Trop. Anim. Agric., 42, 240-246.

[28] Loetscher Y, M Kreuzer and RE Messikommer. (2013). Utility of nettle (Urtica dioica) in layer diets as a natural yellow colorant for egg yolk. Anim. Feed Sci. Technol., 186,158-168.

[29] Soeparno. (2009). Ilmu dan Teknologi Daging, Cetakan III. Gadjah Mada University Press. Yogyakarta.

[30] Puspani E, DPMA Candrawati and IGNG Bidura. (2018). The Effect of aqueous extract of two leaves (Sauropus androgynus and Moringa oleifera) and its combination on egg production, yolk colour and yolk cholesterol levels in egg laying hens. 2018. International Journal of Multidisciplinary Approach and Studies, 05, 23-32.

[31] Firmansyah I, Kardaya D dan and Dihansih E. (2015). Physical quality of local rabbit meat given additional feed soursop leaf flour and zeolite, Jurnal Peternakan Nusantara, 1, 9-16.

[32] Lee MT, WC Lin, B Yu and TT Lee. (2017). Antioxidant capacity of phytochemicals and their potential effects on oxidative status in animals-A review. Asian-Australas J. Anim. Sci, 30, 299-308.

[33] Ouyang K, M Xu, Y Jiang and W Wang. (2016). Effects of alfalfa flavonoids on broiler performance, meat quality and gene expression. Canad. J. Anim. Sci., 96, 332-41.

\section{How to cite this article}

Puspani E, Candrawati DPMA and Bidura IGNG. (2020). Performance, carcasses, cholesterol and beta-carotene of rabbit meat fed with concentrate and carrot (Daucus carota) leaves. GSC Biological and Pharmaceutical Sciences, 12(1), 4147. 